\title{
Halal-friendly tourism and factors influencing halal tourism
}

\author{
Junaidi Junaidi ${ }^{*}$
}

${ }^{a}$ Universitas Lancang Kuning, Indonedia

CHRONICLE ABSTRACT

Article history:

Received: October 9, 2019

Received in revised format: No-

vember 252019

Accepted: January 7, 2020

Available online:

January 7, 2020

Keywords:

Halal Tourism

Halal food

General Islamic values
This study aims to depict the halal tourism concept, its business process, and investigate dilemmas faced by tourism industry and proposes strategies to resolve the constraints based on the best practice from the tourism business operators. In addition, this study tries to investigate the influence of various factors on halal tourism. Triangulation method used by combining personal in-depth interview, documentation/literature review and field observation to generate the discussion and conclusion. Interview process was conducted by selecting four tourism operators in Indonesia who won the best halal category award by The World Halal Travel Award in Dubai. Additionally, for the empirical analysis, a questionnaire was also developed, and data was collected from a total sample of 313 Muslim tourists in the region of Indonesia. Study reveals that instead of taking position as pure sharia-compliant business, all participants chose to become Muslim-friendly business. This moderate business process transformation helps to expand their market segment to Muslim tourists at tolerable cost. The existing dilemmas faced by all entities in tourism industry are as follows: there is no formal standard of halal criteria, high-cost business transition, lack of sharia-competent human resources and lack of promotion. Besides, findings through regression analysis specifies that there is a significant and positive influence of quality and certification of halal food, male serving in the restaurants, halal activities and separate recreational facilities on halal tourism industry. The study was engaged with the best practices from halal business operators. Further research is suggested to involve tourists' perception of halal-related product, management, human resource and finance operated by the halal business operators. Meanwhile, this study has considered a limited number of factors influencing on the halal tourism with traditional analysis approach.

\section{Introduction}

These days, halal substances have become part of many people's lifestyle all over the world. Halal is associated with not only food products but also non-food products; including cosmetics, pharmaceuticals, leather crafts, fragrance, including services such as banking, entertainment, tourism and logistics (Rahim et al., 2013). More specifically in tourism sector, according to Harahsheh (2019), tourism is presently also widely affected by religious beliefs which trigger the emergence of halal tourism. The rapid growth of the halal tourism industry is driven by increased awareness of Muslims on halal tourism as well as the rise of the Muslim population (Markham, 2014; Rahim et al., 2013; Battour \& Ismail, 2016; Battour et al., 2010; Kamran \& Omran, 2018). Travel expenditure of the Muslims may reach US \$ 238 billion by 2019 (Finance, 2015). CresentRating.com reports that Muslim tourists contribute $12.3 \%$ to the world's total tourist spending (Osman et al., 2015). However, many constraints are faced by halal-based tourism operators. First, there is no formal standard of halal criteria available in the management of sharia-compliant tourism business that can be understood and widely accepted by all stakeholders. Although Indonesia is the most populous Muslim country in the world, some halal tourism operators refused the Minister of Tourism and Creative Economy Regulation Number 2 of 2014 on the Guidelines for the Implementation of Sharia Hotel Business that * Corresponding author.

E-mail address: junaidi@unilak.ac.id (J. Junaidi) 
led to the revocation of the regulation. This refusal shows that there is still different perception in viewing sharia tourism among tourism operators. In addition, the fatwa - an official statement or order from an Islamic religious leader - of DSNMUI Number 108/DSN-MUI/X/2016 on Guidelines for Implementing Sharia-Compliant Tourism issued by the National Sharia Board of MUI (The Indonesian Council of Ulama) does not specifically stipulate this matter technically because it merely contains normative rules that must be obeyed by every sharia-compliant tourism provider.

This ironic phenomenon not only takes place in Indonesia but also in other Muslim countries. Egypt and some Middle East countries, for instance, also experience a lack of reference and standards regarding the implementation of sharia-compliant tourism. The implementation of sharia principles in Egypt is even often contrary to state regulations governing the completeness of international hotel facilities for the 4- and 5-star hotel category (Saad et al., 2014). That is why many international hotels refuse the implementation of sharia-compliant hotels (Razalli et al., 2012). Furthermore, the point of view of halal tourism criteria of each country also vary. Zamani-Farahani and Musa (2012) state that even in Muslim countries, their views on the sharia implementation are heterogeneous as the situation differs in each country depending on interpretation of Islam and local culture, the criteria of liberality and intervention of the countries. For example, according to Kovjanic (2014), Egypt, Morocco, the United Arab Emirates and Malaysia are more flexible in implementing sharia in their tourism industry, while Iran, Saudi Arabia and Brunei Darussalam are considered more rigid.

A number of studies related to the challenges and strategies regarding halal tourism industry have been carried out. However, these studies, so far, did not involve tourism business operators who won the world's best prize in the implementation of sharia-compliant business. Their best practice is highly required to understand how a tourism business should actually be done in the midst of a challenging situation where the majority of stakeholders are already familiar with conventional tourism business practice. This study aims to describe the halal tourism concept and investigate dilemmas faced by tourism industry and propose strategies to resolve the constraints.

\section{Literature Review and Discussion}

Tourism theory is important to comprehend the tourism itself (Stergiou \& Airey, 2018; Buhalis, 1998; Hassan, 2000). Tourism will never become an autonomous field of science, because practically it will involve many disciplines, like socio-cultural (Wyllie, 2011). The term of tourism firstly emerged from the habits of wealthy people in England who sent their young men to study throughout Europe (Leiper, 1979). Currently, the term has involved almost all aspects of human life (Ma \& Law, 2009). The concept of tourism according to Chadwick (1994) is a human activity out of the environment where he lives for some time in which the main purpose is to learn or feel the experience of new places. Although Graf and Ossig (2002) claim that travel types does not correlate with tourist's motivation, but other studies reveal that the recognition of socio-cultural of the travel can be a motive for tourists (e.g. Rinschede, 1992; Wyllie, 2011). Tourists are culturally influenced by others who inform them that the travel should be undertaken, desirable and worthy. Therefore, tourism marketers must be able to recognize every tourist's motive. Understanding consumers is the key to success in the tourism industry (Goeldner \& Ritchie, 2009). Moreover, tourism nowadays becomes a global phenomenon with various different types, environments, cultures, and tourist types (Goeldner \& Ritchie, 2009). Some of them even lead to a very specific niche tourism market (special interest) targeting to a particular segment, one of which is the most dynamic is that: halal tourism.

The concept of religious travel according to Rinschede (1992) is identified with the type of travel driven by religious reasons. The form of religious travel might be the oldest form of tourism (Sigaux 1996; Vukonic, 1996). Dogan (2011) proposes different concepts that Islamic tourism includes activities undertaken by Muslims in tourist destinations for relaxation and entertainment purposes, presented by hospitality companies that apply Islamic principles. These principles include the implementation of halal concepts in every travel managed or known as halal or travel tourism.

Battour et al. (2010) define that sharia travel refers to a set of religious values and rules governing human life and interaction of human with all human beings in the world. The form of the tourism can be hijja that is a travel and pilgrimage to Mecca and Medina; zejara which refers to visit to Muslim holy places; rihla, refers to travel for other reasons, such as education, commerce and so forth (Alim et al., 2015). Tourism in Islam consists of five objectives: (a) to worship, such as hajj and umrah, (b) to gain knowledge and experience, (c) to seek scientific truth and thought contained in the Koran, (d) to preach to man elsewhere, (e) to express gratitude and awe of Allah's creation while enjoying the beauty of his creation (Jaelani, 2017).

Islamic teachings strongly encourage followers to travel as written in the holy book of the Koran and the hadith of the prophet Muhammad (Musa et al., 2015). Therefore, there are a number of provisions regarding Islamic tourism as follows (Alim et al., 2015), mustabahah (recommended), it is a travel that aims to preach (dakwah) and to contemplate the signs of nature that can reflect His greatness; mubah (permissible), it is a travel for enjoyment and pleasure but without making any damage (sin); makruh is a travel that should be avoided although it is not sinful. Or in other word, the travel is done for merely entertainment value and has no religious purpose; haram (prohibited), it is a travel done to commit immoral act or sin, to disobey the rights of God and to participate in religious celebrations or rituals/beliefs of other religions but Islam. 
The concept of halal in the context of tourism is evidence of Islamic teachings involvement in every aspect of a Muslim since Islam is a comprehensive religion (Samori et al., 2014). The fundamental beliefs of Muslims are that Islam has a holistic and comprehensive concept and provides solutions to many problems and needs of Muslims through the implementation of various values contained therein (Battour et al., 2010; Kamran et al., 2019). Halal terminology has a range of implementations including human relations, dress and behavior ethics, social and business transactions, trade, services and investments and other aspects in accordance with the principles and directives set forth in Islam (Samori et al., 2014), including the needs to travel that does not violate provisions regulated in Islam.

Henderson (2010) states that halal in Arabic terminology refers to 'permitted' or 'allowed'. This concept is not only for food but also cosmetics, vaccines and tourism. In addition to eating and drinking, doing anything in accordance with Islamic law and principles can be interpreted as halal (Samori et al., 2014), because the concept of halal refers to ways to produce goods and services that are allowed in Islamic law (Abdul, 2013). The emphasis of halal tourism is on the proper movement which is an element of spiritual travel in service to God. Sharia law determines what is acceptable (halal) and what is unacceptable (haram) in everyday life and during the travel (Kovjanic, 2014). In the view of Islam, people cannot act arbitrarily in the world. Through sharia law, man who lives and interacts in the world must realize that anything they do will be reckoned in the hereafter (Battour et al., 2010), which in Islamic terminology is called as hisab.

\section{Research Design}

Exploratory study was employed with the intention to find out the best practice and assess the most ideal strategy of halaltourism operation. In order to fit the purpose, a qualitative approach and in-depth interview with observation was conducted (Creswell, 2014). Semi-structured interview was designed to open more possibility in generating information. The interview duration took approximately one hour. All conversations were recorded, transcribed and finally analyzed using the content analysis which is a technique for making replicable and valid inferences from texts and lets to discover what the text reveals (Sekaran \& Bougie, 2013). The interview interpretation then analyzed by triangulation method to check and recheck with other sources, such as books, research results, and official reports to validate the information (Sugiyono, 2015). The participants are a number of Indonesia successful halal tourism operators - at least on the basis of the award they received from World Halal Travel Award in Dubai - to be the best in a number of halal tourism assessment categories, such as: (1) Hotel Sofyan, located in Jakarta that was awarded as The World's Best Family Friendly Hotel in 2015; (2) The Radhana Hotel, located in Kuta - Bali, that won the World Best Family Friendly Hotel in 2016; 3) Novotel Lombok Resort and Villas, located in Lombok - West Nusa Tenggara, that won the World Best Halal Beach Resort in 2016; (4) Sembalun Village Region, Lombok - located in West Nusa Tenggara, that achieved the World Best Halal Honeymoon Destination in 2016. The participants contacted by email to set the meeting on site.

In addition, this study has developed a structural questionnaire, considering the factors of halal food (measured through five items), general Islamic values (measured through five items), Muslim friendly holiday packages (measured through six items), and miscellaneous Islamic factors (measured through five items). All these factors are measured on the Likert scale, ranging from strongly disagree as 1 , and strongly agree as 5 respectively. Meanwhile, the factor of halal tourism was also added in the questionnaire and presented through five items. After the development of questionnaire, various respondents are targeted (mainly the Muslim tourists) and a sample of 313 respondents was finally collected.

\section{Results and Discussion}

Table 1 describes the descriptive findings through mean, deviation and minimum-maximum observations. It is found that for the factors of halal food, maximum mean score is 3.79 as presented by availability AV, followed by HYG which is 3.31 respectively. Meanwhile, deviation from the mean score is highest for ease-in access factor; 133 . For the $2^{\text {nd }}$ measurement of factors affecting the halal tourism, this study has considered the title of general Islamic values. For this purpose, five items are under observation where highest mean trend belongs to avoidance of music; 3.67, followed by dress-code; 3.17 . In addition, for the factors under the title of Muslim friendly holiday's packages, overall six items are presented. The mean score for HACT is 2.98, while for PF it is 3.39, and for PRIF it is 3.086 respectively. In addition, remaining factors have also shown a good trend in terms of mean and standard deviation of the collected responses. The fourth dimension to analyze its influence on halal tourism is entitled as miscellaneous Islamic values, covering three items. It shows that FEMS has a highest mean score of 3.319, followed by SCF and IE with the relative mean score of 3.099 and 3.051 respectively. Meanwhile, for halal tourism (HT), five items are also presented under Table 1 with their respective mean score and deviation from the mean as well. For checking the impact of halal food factors on halal tourism, Table 2 provides regression findings. It is found that QUL has a positive and significant influence on mean score of HT with the coefficient of .146 and standard error of 0.054 respectively. It shows that more the quality of halal foods, positive the influence on halal tourism as expected by various Muslim tourists. Meanwhile the influence of HYG is also found to be positively significant on Mean HT with the standardized coefficient of 0.102 , significant at 5 percent. It indicates that hygienic factor is found to be a positive indicator to influence on halal tourism. However, there is no significant influence on Mean HT by the remaining factors under the title of halal food as observed. In addition, Fig. 1 provides the structural model as presented through empirical findings under Table 2. 
Table 1

Descriptive Statistics

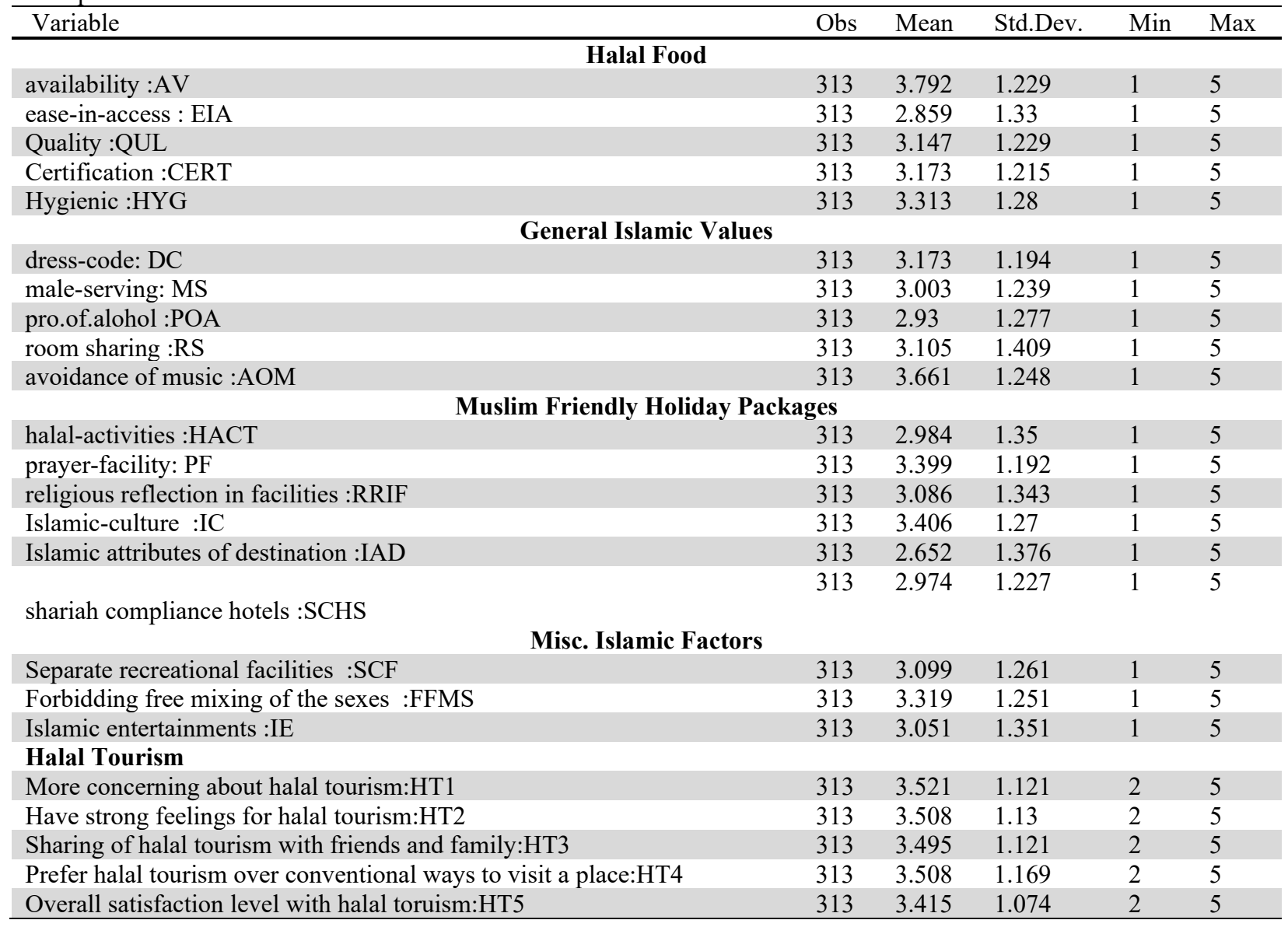

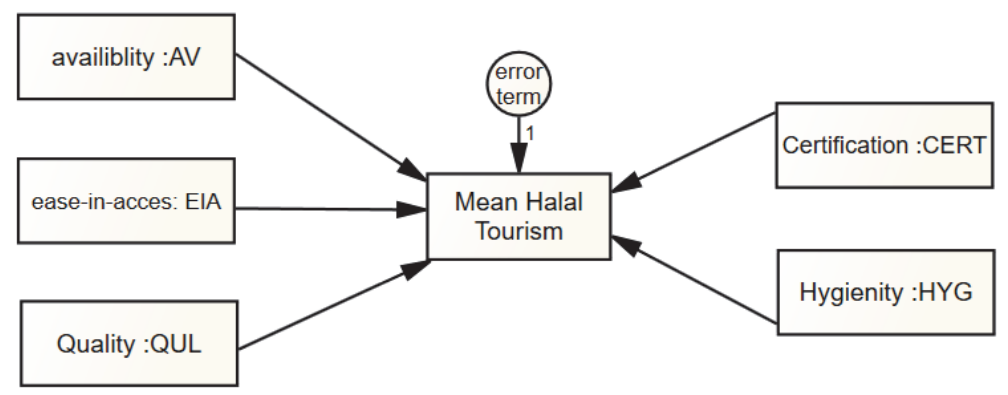

Fig. 1. Impact of Halal Food Characteristics on Halal Tourism

Table 2

Halal Food and Halal Tourism

\begin{tabular}{|c|c|c|c|c|c|}
\hline Mean HT & Coef. & St.Err & t-value & p-value & Sig. \\
\hline availability :AV & 0.026 & 0.054 & 0.47 & 0.636 & \\
\hline ease-in-access : EIA & -0.027 & 0.049 & -0.55 & 0.584 & \\
\hline Quality :QUL & 0.146 & 0.054 & 2.69 & 0.008 & $* * *$ \\
\hline Certification :CERT & 0.041 & 0.053 & 0.77 & 0.439 & \\
\hline Hygienic :HYG & 0.102 & 0.050 & 2.06 & 0.040 & $* *$ \\
\hline cons & 3.489 & 0.300 & 11.62 & 0.000 & $* * *$ \\
\hline Mean dependent var & \multicolumn{2}{|c|}{3.521} & SD dependent var & \multicolumn{2}{|c|}{1.124} \\
\hline R-squared & \multicolumn{2}{|c|}{0.038} & Number of obs & \multicolumn{2}{|c|}{313.000} \\
\hline F-test & \multicolumn{2}{|c|}{2.405} & Prob $>$ F & \multicolumn{2}{|c|}{0.037} \\
\hline Akaike crit. (AIC) & \multicolumn{2}{|c|}{958.765} & Bayesian crit. (BIC) & \multicolumn{2}{|c|}{981.243} \\
\hline
\end{tabular}


Table 3 shows the empirical results for the general Islamic values and their influence on Halal Tourism as observed through mean score. It is found that factor of halal tourism is positively and significantly influence by the male serving facility. The value of coefficient for MS is 0.422 and standard error of 0.054 respectively. This effect is significant at 1 percent, with the t-value of 7.81. In addition, the rest of the indicators have shown their insignificant influence on halal tourism, which needs to be revised in upcoming studies. Fig. 2 provides the overview for the structural model, covering the impact of general Islamic values on halal tourism.

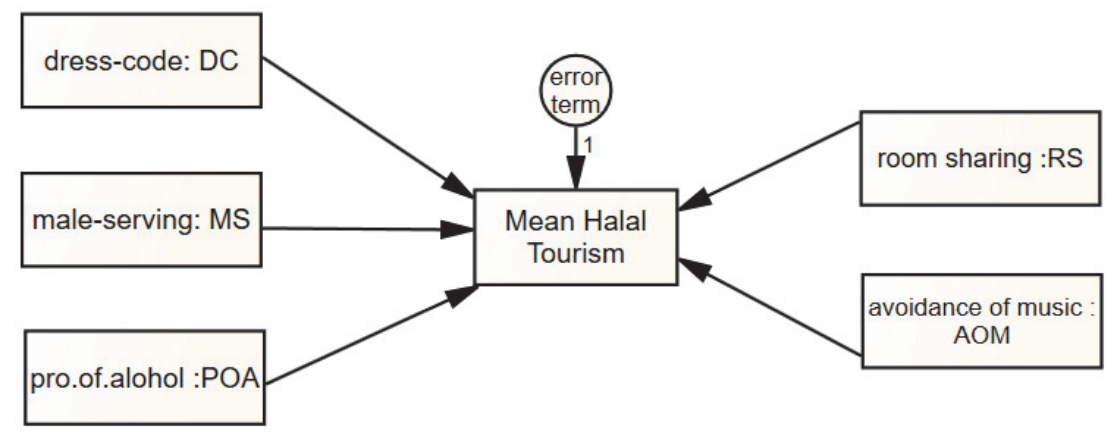

Fig. 2. Impact of General Islamic Values on Halal Tourism

Table 3

General Islamic Values and Halal Tourism

\begin{tabular}{|c|c|c|c|c|c|}
\hline Mean HT & Coef. & St.Err & t-value & p-value & Sig. \\
\hline dress-code: DC & 0.010 & 0.066 & 0.16 & 0.874 & \\
\hline male-serving: MS & 0.422 & 0.054 & 7.81 & 0.000 & $* * *$ \\
\hline pro.of.alohol :POA & -0.047 & 0.063 & -0.75 & 0.456 & \\
\hline room sharing : $\mathrm{RS}$ & -0.015 & 0.051 & -0.29 & 0.774 & \\
\hline avoidance of music :AOM & -0.023 & 0.055 & -0.42 & 0.675 & \\
\hline cons & 3.628 & 0.264 & 13.72 & 0.000 & $* * *$ \\
\hline Mean dependent var & \multicolumn{2}{|c|}{3.521} & SD dependent var & \multicolumn{2}{|c|}{1.124} \\
\hline R-squared & \multicolumn{2}{|c|}{0.150} & Number of obs & \multicolumn{2}{|c|}{313.000} \\
\hline F-test & \multicolumn{2}{|c|}{0.314} & Prob $>$ F & \multicolumn{2}{|c|}{0.904} \\
\hline Akaike crit. (AIC) & \multicolumn{2}{|c|}{969.192} & Bayesian crit. (BIC) & \multicolumn{2}{|c|}{991.669} \\
\hline
\end{tabular}

Table 4 shows the regression findings for the impact of Muslim friendly holiday packages indicators on the mean score of halal tourism. It is observed that halal activities as under the shariah guidance has shown its positive and significant influence on mean value of HT with the coefficient of 0.111 . It explains that there is a positive and direct influence of HACT on Mean HT under full sample of the study. However, the impact through PR, RRIF, IC and IAD is found to be insignificant, specifying that there is no influence of these indicators on Mean HT. In addition, the factor of Shariah compliance hotels or SCHS has shown its positive and highly significant impact on mean value of halal tourism. The coefficient of .871 explains that more the shariah compliance in the hotels, more the decent impact on halal tourism. Fig. 3 shows the relationship between Muslim friendly holidays and halal tourism.

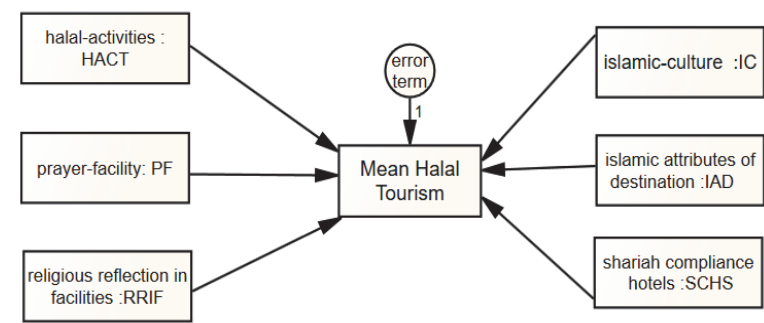

Fig. 3. Impact of Muslim friendly Holidays on Halal Tourism

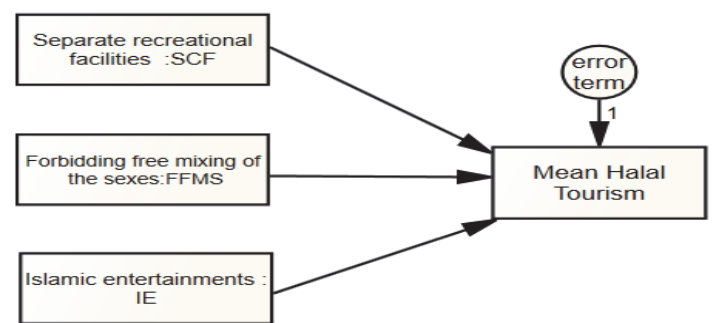

Fig. 4. Impact of Misc. Islamic factors on Halal Tourism 
Table 4

Muslim Friendly Holiday Packages and Halal Tourism

\begin{tabular}{|c|c|c|c|c|c|}
\hline Mean HT & Coef. & St.Err & t-value & p-value & Sig. \\
\hline halal-activities :HACT & 0.111 & 0.053 & 2.11 & 0.036 & $* *$ \\
\hline prayer-facility: PF & 0.036 & 0.059 & 0.61 & 0.543 & \\
\hline religious reflection in facilities :RRIF & -0.020 & 0.054 & -0.37 & 0.710 & \\
\hline Islamic-culture :IC & -0.034 & 0.054 & -0.62 & 0.534 & \\
\hline Islamic attributes of destination :IAD & -0.045 & 0.049 & -0.92 & 0.360 & \\
\hline shariah compliance hotels :SCHS & 0.871 & 0.159 & 5.47 & 0.000 & $* * *$ \\
\hline cons & 3.768 & 0.264 & 14.26 & 0.000 & $* * *$ \\
\hline Mean dependent var & 3.521 & \multicolumn{2}{|c|}{ SD dependent var } & \multicolumn{2}{|c|}{1.121} \\
\hline R-squared & 0.023 & \multicolumn{2}{|c|}{ Number of obs } & \multicolumn{2}{|c|}{313.000} \\
\hline F-test & 1.222 & \multicolumn{2}{|c|}{ Prob $>$ F } & \multicolumn{2}{|c|}{0.294} \\
\hline Akaike crit. (AIC) & 965.377 & \multicolumn{2}{|c|}{ Bayesian crit. (BIC) } & \multicolumn{2}{|c|}{991.600} \\
\hline
\end{tabular}

Table 5 provides the findings for the impact of Misc. Islamic factors and their influence on Halal Tourism. It is observed that only the factor of separate recreational facilities is found to be significant and positive indications of halal tourism. The coefficient of 0.102 specifies that more the SCF, positive the impact on Mean HT under full sample of this research. In addition, the other factors like forbidding free mixing of gender, and Islamic entertainments have shown their insignificant but negative influence on halal tourism. It means that although both of these are adversely influencing on halal tourism, yet their influence cannot be accepted due to insignificant p-values. Fig. 4 indicates the impact of Misc. Islamic factors on Halal Tourism.

Table 5

Misc. Islamic Factors and Halal Tourism

\begin{tabular}{|c|c|c|c|c|c|}
\hline Mean HT & Coef. & St.Err & t-value & p-value & Sig. \\
\hline Separate recreational facilities :SCF & 0.102 & 0.057 & 1.80 & 0.072 & $*$ \\
\hline Forbidding free mixing of the sexes :FFMS & -0.089 & 0.057 & -1.56 & 0.119 & \\
\hline Islamic entertainments :IE & -0.044 & 0.052 & -0.84 & 0.402 & \\
\hline cons & 3.632 & 0.214 & 16.98 & 0.000 & $* * *$ \\
\hline Mean dependent var & 3.521 & \multicolumn{2}{|c|}{ SD dependent var } & \multicolumn{2}{|c|}{1.121} \\
\hline R-squared & 0.016 & \multicolumn{2}{|c|}{ Number of obs } & \multicolumn{2}{|c|}{313.000} \\
\hline F-test & 1.690 & \multicolumn{2}{|c|}{ Prob $>F$} & \multicolumn{2}{|c|}{0.169} \\
\hline Akaike crit. (AIC) & 961.696 & \multicolumn{2}{|c|}{ Bayesian crit. (BIC) } & \multicolumn{2}{|c|}{976.681} \\
\hline
\end{tabular}

\section{Discussion for the Interview Findings}

This study synthesized all participants' interviews revealing that the best practices undertaken by the award winners of halal tourism are to strive in fulfilling the fundamental aspects of the formal standard of halal criteria for Muslim tourists, namely the provision of halal food certified by the Indonesian Council of Ulama and prayer facilities in terms of both quantity and quality. Halal certification is not only for the tourism operators, but also suppliers of the tourism operators. The most important product or service that must be fulfilled in the implementation of sharia-compliant tourism is the provision of halal food and beverages and the ease of worship (COMCEC, 2016). This is confirmed by the Standing Committee for Economic and Commercial Cooperation of the Organization of Islamic Cooperation (COMCEC) in 2016 classifying the formal standard of halal criteria into: 'need to have' consisting of halal food and prayer facilities; 'good to have' consisting of a bathroom with clean and sufficient water; services and facilities in the fasting month, and; 'nice to have' consisting of non-halal activities as well as recreational facilities and services. Thus, the two most important elements of the implementation of sharia principles which are halal food and prayer facilities have been completely fulfilled by the participants.

Certification is necessary to guarantee the halal food because it is endorsed by an authorized institution and becomes an official recognition that a product is permissible under Islamic law. This certificate will help consumers gain assurance without any suspicion or doubt in consuming products and services (Eddahar, 2016), especially to ensure that food does not contain non-halal essence and animals served are slaughtered in accordance with the Sharia law (Battour et al., 2010). Since doing a prayer is a major obligation of Muslims, therefore the fulfillment of prayer facilities is in the top priority. Some of the needs that have to be fulfilled are clean and hygienic prayer room, sufficient water, prayer equipment and The Koran (Idris \& Wahab, 2015; Battour et al., 2010). The implementation of management or operation is clearly arranged in the form of Standard Operational Procedure (SOP) disseminated to all operators. Preparation and supervision of the SOP is regularly discussed with the National Sharia Council - Indonesia Council of Ulama (MUI) so that the SOP is in accordance with the principles of sharia in each of the category. The SOP is consistently implemented with high commitment. This is the synthesis of all interviews with respondents dealing with halal operation. 
The management process shows how products and services are presented to users (Asnawi \& Fanani, 2017). In the end, the winners implement the halal principles in certain services consistently and firmly. Even though in Bali that the population majority is non-Muslims, if halal principles are consistently implemented, halal tourism will run successfully. In the beginning, it may be difficult indeed to run halal business there. On the contrary, when halal business is run in a predominantly Muslim region, the level of difficulty might be lower. The operators of halal tourism should be aware that halal has become the lifestyle of the world's consumers today (Rahim et al., 2013), so it is not only for Muslim consumers but also for nonMuslims. The non-Muslim consumers demand halal products and services not for the sake of religion but health and comfort instead. In addition, Muslim tourists are more and more critical with the guarantee of halal as Muslim tourists have better awareness of the importance of halal tourism (Zulkifli et al., 2011).

The implementation of a clear SOP regarding a work process must meet certain halal requirements. The formulation of SOP should be standardized that it can be understood and implemented by all stakeholders. In short, SOP is not only for tourism operators but also for the tourists. In the context of tourism, standardization is an effort to improve facilities, procedures, and actions in a certain way to ensure the quality of services provided to customers has met the needs of tourists.

Aspects of Human Resource - What this study synthesized from the interviews with all participants regarding human resource management is that the character building and competence of tourism operators to provide halal-based services is implemented by providing special training related to the practice of halal service and giving religious speech (tausyah) on halal products and services regularly. Even if the employees are not Muslim, they must follow all SOPs in providing shariacompliant business services, especially regarding hygiene, separation between halal (allowed) and haram (forbidden), which is highly obliged in Islamic teachings.

\section{Conclusions and Implications}

Halal tourism has tremendous potentials to be developed along with rise of Muslim consumer awareness of keeping the values of the sharia even in tourism activities. It occurs because the teachings of Islam set not only worshiping God but also directing the relationship between human beings (muamalah). The concept of halal tourism, then, becomes a concept of tourism containing certain needs. Both findings of interview and literature review reveal that in order to fulfill the needs requires a number of extra costs in order to be sharia-compliant tourism or just to be friendly Muslim tourism. The additional cost often is a constraint for tourism business operators who intend to change their business process from the conventional to the halal concept or who really intend to run a halal tourism business from the very beginning.

Our proposed solution is to impose a premium pricing practice in halal tourism services. Psychological pricing practice is no longer based on functional and rational benefits which is commonly used in conventional marketing practices, but based on emotional and spiritual reasons instead. Therefore, promotion and education to foster awareness of maintaining the values of the sharia in tourism business are required. The best way to do is to inform customers and make them aware why the concept of halal tourism business is different from the conventional ones, so that the price of halal business products is more expensive. If it can be done consistently, halal business operators will be no longer worried about potential of loss. What might happen is not the loss of customers, but the shift of customer segments from the conventional to specific customers who care about the halal tourism products and services. If this is applicable, halal tourism operators will not be in a dilemma. Then, it is now on the consumers' hand whether they still want to pay cheaply for tourism products and services that has no halal guarantee, or pay a bit more money to consume halal-guaranteed tourism product or services. The perspectives of this study are mostly based on the best practices conducted by the participants which are the world best halal operators. However, this research did not measure tourist's perspective regarding to the aspect of halal-related products, management, human resource and finance. Further study may be conducted to find out whether those halal-business aspects implementation could satisfy Muslim tourist's need and want. Meanwhile, this study specifies that halal tourism has been affected by variety of factors, with their positive and significant influence. However, it is highly recommended that future studies could observe the study findings for the empirical association between the halal food, holiday packages, misc. Islamic factors, and general Islamic values for their influence on halal tourism.

\section{References}

Alim, H.T., Riansyah, A.O., Hidayah, K., Muslim, I., \& Adityawarman. (2015), Analisis potensi pariwisata syariah dengan mengoptimalkan industri kreatif di jawa tengah dan yogyakarta, Jurnal Akuntansi FEB Universitas Diponegoro, Semarang, 1-8.

Asnawi, N., \& Fanani, M.A. (2017), Pemasaran Syariah: Teori, Filosofi, dan Isu-Isu Kontemporer, Rajagrafindo Persada, Depok.

Battour, M.M., Ismail, M.N., Battor, M. (2010). Toward a halal tourism market. Tourism Analysis, 15, 1-10.

Battour, M., \& Ismail, M. N. (2016). Halal tourism: Concepts, practices, challenges and future. Tourism Management Perspectives, 19, 150-154.

Battour, M. M., Ismail, M. N., \& Battor, M. (2010). Toward a halal tourism market. Tourism Analysis, 15(4), $461-470$.

Buhalis, D. (1998). Strategic use of information technologies in the tourism industry. Tourism Management, 19(5), $409-421$. 
Chadwick, R.A. (1994). Concepts, Definitions, and Measures Used in Travel and Tourism Research. Travel, Tourism, and Hospitality Research: A Handbook for Managers and Researchers, J.R.B. Ritchie and C.R. Goeldner, eds., 66, John Wiley, New York.

COMCEC. (2016), Muslim Friendly Tourism: Understanding the Demand and Supply Sides in the OIC Member Countries. Rederived from: http://www.comcec.org/wp-content/uploads/2016/05/7-TUR-AN.pdf.

Creswell, J.W. (2014). Research design: qualitative, quantitative \& mixed methods approaches, $4^{\text {th }}$ ed., Sage Publication, London.

Dogan, M. (2011). Turkiye deislamiturizmingelisimi 2002-2009 in political economy, crises and development, Istanbul: IJOPEC Publication, 471-487.

Eddahar, N. (2016). Muslim friendly tourism branding in the global market, Research Report of Islamic Center for the Development of Trade by Organization of Islamic Cooperation. Rederived from: https://www.oic-oci.org/docdown/?do$\underline{\mathrm{cID}=1772 \& \mathrm{refID}=1071}$

Goeldner, C.R., \& Ritchie, J.R.B. (2009). Tourism: principles, practices, philosophies. $11^{\text {th }}$ ed., John Willey \& Sons, Inc., New Jersey.

Graf, L., \& Ossig, C. (2002). Review of the concept of travel typologies: The case of Switzerland. Tourism Review, 57(4), 28-32.

Hassan, S. S. (2000). Determinants of market competitiveness in an environmentally sustainable tourism industry. Journal of Travel Research, 38(3), 239-245.

Jaelani, A. (2017), Halal tourism industry in Indonesia: Potential and prospects, Munich Personal RePec Archieve (MPRA) Paper No. 76235. Retrieved from https://mpra.ub.uni-muenchen.de/76235/

Kamran, H. W., \& Omran, A. (2018). Impact of environmental factors on tourism industry in Pakistan: A study from the last three decades, The Impact of Climate Change on Our Life, 197-212: Springer.

Kamran, H. W., Mohamed-Arshad, S. B., \& Omran, A (2019). Country governance, market concentration and financial market dynamics for banks stability in Pakistan. Research in World Economy, 10(2), 136-146.

Kovjanic, G. (2014). Islamic tourism as a factor of the Middle East, Turizam, 18(1), 33-43.

Leiper, N. (1979). The framework of tourism: Toward a definition of tourism, tourist and the tourist Industry, Annals of Tourism Research, 6(4), 390-407.

Ma, J., \& Law, R. O. B. (2009). Components of tourism research: Evidence from annals of tourism research. Anatolia, 20(1), 62-74.

Markham, D. (2014). Fluorishing halal tourism sector offers business opportunities. Retrieved from ecopreneurs. Retrieved from http://www.ecopreneurist.com.

Musa, G., Ali, S. Bt. M., \& Moghavvemi, S. (2015). Understanding islamic (halal) tourism through Leiper's tourism system. SSRN Electronic Journal, retrieved from https://www.researchgate.net/publication/ 305491320

Razalli, M., Suzzaini, A., \& Ghozali, H. (2012). Developing a model for islamic hotels: Evaluating opportunities and challenges, International Proceeding of Economic Development and Research, 42, 91-95.

Rinschede, G. (1992), Forms of religious tourism, Annals of Tourism Research, 19, 51-67.

Saad, H.E., Ali, B.N., \& Abdel Ati, A.M. (2014), Sharia compliant hotels in Egypt: Concept and challenges, Advance in Hospitality and Tourism Research, 2(1), 1-15.

Samori, Z., Ishak, A.H. and Kassan, N.H. (2014), Understanding the development of halal food standard: Suggestion for future research, International Journal of Social Science and Humanity, 4(6), 482-486.

Sekaran, U. and Bougie, R. (2013), Research methods for business: A skill-building approach, $6^{\text {th }}$ ed., John Wiley \& Sons, Inc., West Sussex.

Sigaux, J. (1996), History of tourism. Leisure Arts, London.

Stergiou, D.P., \& Airey, D. (2018), Understanding the tourism theory, Tourism Review, 73(2), 156-168.

Sugiyono. (2015), Metode penelitian manajemen. Alvabeta, Bandung.

Vukonic, B. (1996), Tourism and religion. Pergamon, Oxford.

Wyllie, R.W. (2011). An introduction to tourism. Venture Publishing, Inc., Illinois.

Zulkifli, W.S.W., Ab Rahman, S., Awang, K.W., \& Che Man, Y.B. (2011). Developing the framework for halal friendly tourism in Malaysia. International Business Management, 5(6), 295-302.

Zamani-Farahani, H., \& Musa, G. (2012). The relationship between Islamic religiosity and residents' perceptions of sociocultural impacts of tourism in Iran: Case studies of Sare'in and Masooleh. Tourism Management, 33(4), 802-814.

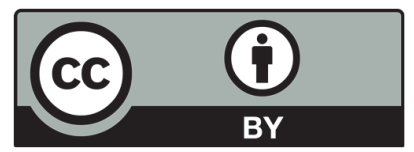

(C) 2020 by the authors; licensee Growing Science, Canada. This is an open access article distributed under the terms and conditions of the Creative Commons Attribution (CC-BY) license (http://creativecommons.org/licenses/by/4.0/). 